\title{
Pengaruh Permainan Puzzle terhadap Kreativitas Anak Prasekolah (4-5 tahun) di TK Al-Kholifah Selorejo - Jombang
}

\author{
The Effect of Puzzle Game to Preschool Children's Creativity (4-5 years) in TK Al-Kholifah \\ Selorejo-Jombang \\ Ferilia Adiesti \\ Progam Studi D-III Kebidanan \\ Sekolah Tinggi Ilmu Kesehatan Majapahit Mojokerto, Jawa Timur \\ *Corresponding author : f.adiesti april86@yahoo.co.id
}

\begin{abstract}
ABSTRAK
Kemampuan kognitif berperan penting dalam perkembangan kreativitas. Kemampuan kreativitas akan menentukan bagaimana materi yang diberikan dapat ditangkap untuk digunakan. Bermain puzzle dapat merangsang peningkatan kemampuan kreativitas. Penelitian ini bertujuan mengetahui pengaruh bermain puzzle terhadap kreativitas anak prasekolah (4-5 tahun).

Penelitian ini dilakukan metode Quasi eksperimen dengan rancangan non equivalent kontrol group. Jumlah sampel yang digunakan adalah 34 responden. Variabel independen adalah bermain puzzle sedangkan variabel dependen adalah kreativitas anak prasekolah (4-5 tahun). Penelitia ini dilakukan dengan pemberian bermain puzzle setiap hari sebelum pelajaran dimulai selama 10 menit.

Setelah bermain puzzle paling besar responden kelompok kontrol memiliki kreativitas pada tingkat rendah yaitu sebanyak 9 responden (53\%) sedangkan kelompok perlakuan yang paling kecil pada level tinggi yaitu 9 responden

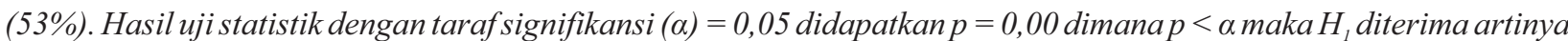
ada pengaruh bermain puzzle terhadap kreativitas anak prasekolah (4-5 tahun).

Bermain puzzle dapat merangsang peningkatan kreativitas dengan pemberian terapi bermain puzzle secara teratur. Karena stimulus yang diberikan akan menentukan bagaimana perkembangan kreativitas anak nantinya. Diharapkan jadi bahan kajian pada perkembangan anak mengenai pengaruh bermain puzzle terhadap kreativitas anak prasekolah dan sebagai pedoman dalam memberikan health education (HE) tentang jenis permainan yang sesuai dengan usia anak.
\end{abstract}

Kata Kunci : Permainan Puzzle, Kreativitas

\section{ABSTRACT}

Cognitive capability has an important role in creativity development. Capability of creativity will determine how the lesson given will be able to be used. Play puzzle can stimulate the increase of creativity capability. This experiment has purpose for knowing the influence of play puzzle to the creativity level at preschool children (4-5 years).

This experiment was Quasy experiment with structure scheme the as samples non equivalent control group. There was 34 respondents. The dependent variable experimented are creativity at preschool children (4-5 years) before and after given play puzzle. This experiment was done during 2 weeks with giving puzzle at every day before the lesson begun in 10 minutes.

After given play puzzle a biggest part of control group responden has level of creativity at low those are 9 respondents (53\%) even a most little part of action group has creativity level at high those are 9 respondent (53\%). According to the statistic test result with of significance degree $(\alpha)=0,05$ gotten $p=0,00$ where $p<\alpha$ so $H_{1}$ received means there is influence of play puzzle to the creativity level at preschool children (4-5 years).

Play puzzle could stimulate the increase of creativity by giving play puzzle therapy continuously. Cause the stimulation given will determine how the development of children creativity capability later. This experiment is hoped become a new knowledge about the influence of play puzzle to creativity of preschool children and as guide in giving health educatioan (HE) about kinds of playing according to the child age.

Key Word : Puzzle Game, Creativity 


\section{PENDAHULUAN}

Bermain mempunyai arti sangat penting bagi anak, yaitu untuk memenuhi kepuasan fisik, emosi dan perkembangan mental sehingga anak dapat mengekspresikan perasaan tentang kekuatan, kesepian, fantasi ataupun menunjukkan kreatifitasnya. Hal ini sangat penting disadari oleh para perawat ruang anak, yang sepanjang hari mereka berhubungan dengan anak-anak sebagai pasien, sehingga kebutuhan dan keperluan anak akan dapat terpenuhi secara optimal dengan kondisi keterbatasan yang dialaminya. Untuk itu diperlukan sikap yang positif dari para perawat tentang upaya pemenuhan kebutuhan bermain anak tersebut. Kecerdasan dan kreativitas anak dapat dioptimalkan salah satunya dengan bermain puzzle. Bermain puzzle adalah kegiatan menyusun kepingan gambar sehingga menjadi sebuah gambar yang utuh yang sangat bermanfaat bagi anak prasekolah (Garahacendikia, 2009)

Masa anak usia prasekolah adalah masa keemasan (golden age) yang mempunyai arti penting dan berharga karena masa ini merupakan pondasi bagi masa depan anak. Menurut Munandar(2004:10) bahwa masa usia pra sekolah adalah tahun-tahun paling efektif dalam kehidupan manusia untuk mengembangkan kreativitas. Karena dengan berkreasi anak dapat mewujudkan dirinya dan ini merupakan kebutuhan pokok manusia. Hal ini sangat penting sebab manusia yang sehat jasmani dan rohaninya akan mampu mengekspresikan diri, dengan menggunakan semua kemampuannya sehingga akan memperkaya hidupnya. Kreativitas atau cara berfikir kreatif, dalam arti kemampuan untuk melihat berbagai kemungkinan dalam pemecahan masalah, masih kurang diperhatikan dalam pendidikan formal. Anak didik dalam pembelajarannya di sekolah lebih menekankan pada cara berfikir secara konvergen yaitu kemampuan berfikir menuju satu-satunya jawaban yang benar.

Menurut Keith Osborn Puncak kecerdasan anak terjadi sejak dilahirkan sapmai usia 5 tahun. Hampir 50\% potensi kecerdasannya diyakini sudah terbentuk diusia 4 tahun. Sedangkan kreativitasnya mulai meningkat pada usia 3 tahun dan mencapai puncaknya pada usia 4,5 tahun (Ismail, 2006: 263).

\section{METODE PENELITIAN}

Desain yang digunakan dalam penelitian ini adalah Quasi Eksperimen (Eksperimen semu), dengan rancangan Non Equivalent Control Group. Rancangan penelitian adalah non random control group pretest post test. Pada penelitian ini peneliti membagi responden menjadi dua kelompok, yaitu kelompok perlakuan dan kelompok kontrol yang tidak dilakukan secara random. Awalnya peneliti mengukur kreativitas menggunakan metode pertanyaan atau kuesioner pada kelompok perlakuan dan kelompok kontrol sebelum dilakukan bermain puzzle, selanjutnya pada kelompok perlakuan dilakukan bermain puzzle sedangkan pada kelompok kontrol tidak dilakukan bermain puzzle. Kemudian dilakukan kembali pengukuran kreativitas dengan metode pertanyaan atau kuesioner pada kelompok perlakuan dan kelompok kontrol. Variabel Independen (variabel bebas) dalam penelitian ini adalah bermain puzzle. Variabel dependen dalam penelitian ini adalah kreativitas anak usia prasekolah (4-5 tahun). Populasi dalam penelitian ini adalah seluruh anak usia prasekolah (4-5 tahun) di TK AlKholifa Selorejo- Jombang. Berdasarkan Besar sampel dengan menggunakan rumus diatas adalah 34 anak.

Penelitian ini dilaksanakan di TK TK AlKholifa Selorejo- Jombang.

Teknik pengumpulan data yaitu:

a. Pertama menetukan responden yang terdiri dari kelompok perlakuan dan kelompok 
kontrol.

b.Kedua, membagi kelompok yang akan melakukan bermain puzzle dan kelompok yang tidak melakukan bermain puzzle.

c. Ketiga, mengukur kreativitas pada kedua kelompok sebelum melakukan bermain puzzle dengan metode pertanyaan atau kuesioner.

d.Keempat, pada kelompok perlakuan dilakukan bermain puzzle. Bermain puzzle yang dilakukan antara lain: Lepaskan kepingan puzzle dari papannya.

1)Acak kepingan puzzle tersebut.

2)Mintalah anak memasangkannya kembali.

3)Berikan tantangan kepada anak untuk melakukannya dengan cepat. Alat yang digunakan antara lain: Kuesioner kreativitas anak prasekolah

\section{HASIL DAN PEMBAHASAN}

\section{Hasil Penelitian}

Pada Penelitian Pengaruh Perminan puzzle terhadap kreativitas pada anak usia prasekolah (4-5 tahun) di TK Al- Kholifah Selorejo Jombang .

\section{Karakteristik Responden}

a. Data Umum Responden

1) Karakteristik Responden Berdasarkan Jenis Kelamin Anak

Tabel 1 menggambarkan bahwa sebagian besar responden berjenis kelamin laki-laki yaitu sebanyak 24 responden $(71 \%)$.

\section{2) Karakteristik Responden Berdasarkan Umur Anak}

Tabel 2 menggambarkan bahwa sebagian besar responden berumur 5 tahun yaitu sebanyak 30 responden $(88 \%)$.

\section{b. Data Khusus}

1) Karakteristik Responden Berdasarkan Kreativitas Anak Pra Sekolah Sebelum Diberikan Bermain Puzzle (kelompok perlakuan).

Tabel 3 menggambarkan bahwa lebih dari $50 \%$ responden (kelompok perlakuan) mempunyai kreativitas rendah yaitu sebanyak 9 responden (53\%).

2) Karakteristik Responden Berdasarkan Kreativitas Anak Pra Sekolah yang Tidak Diberikan Bermain Puzzle (kelompok kontrol).

Tabel 4 menggambarkan bahwa lebih dari $50 \%$ responden (kelompok kontrol) mempunyai kreativitas rendah yaitu 9 responden $(53 \%)$.

3) Karakteristik Responden Berdasarkan Kreativitas Anak Pra Sekolah Sesudah Diberikan Bermain Puzzle (kelompok perlakuan).

Tabel 5 menggambarkan bahwa lebih dari $50 \%$ responden (kelompok perlakuan) mempunyai kreativitas tinggi yaitu sebanyak 9 responden $(53 \%)$.

Tabel 1 Distribusi Responden Berdasarkan Jenis Kelamin Anak di TK Al - Kholifah Selorejo - Jombang.

\begin{tabular}{|c|c|c|}
\hline $\begin{array}{c}\text { Jenis } \\
\text { Kelamin }\end{array}$ & Jumlah & Persentase \% \\
\hline Laki-laki & 24 & $71 \%$ \\
\hline Perempuan & 10 & $29 \%$ \\
\hline Total & 34 & $100 \%$ \\
\hline
\end{tabular}

Tabel 2 Distribusi Responden Berdasarkan Umur Anak di TK Al- Kholifah Selorejo - Jombang

\begin{tabular}{|c|c|c|}
\hline Umur & jumlah & Persentase $\%$ \\
\hline 5 tahun & 30 & $88 \%$ \\
\hline 4 tahun & 4 & $12 \%$ \\
\hline Total & 34 & $100 \%$ \\
\hline
\end{tabular}


Tabel 3 Distribusi Responden (kelompok perlakuan) Berdasarkan Kreativitas Anak Pra Sekolah Sebelum Bermain Puzzle di TK Al- Kholifah Selorejo - Jombang.

\begin{tabular}{|l|c|c|}
\hline Kreativitas & Jumlah & Persentase \% \\
\hline Rendah & 9 & $53 \%$ \\
\hline Sedang & 6 & $35 \%$ \\
\hline Tinggi & 2 & $12 \%$ \\
\hline \multicolumn{1}{|c|}{ Total } & 17 & $100 \%$ \\
\hline
\end{tabular}

Tabel 4 Distribusi Responden (kelompok kontrol) Berdasarkan Kreativitas Anak Pra Sekolah Sebelum Bermain Puzzle di TK Al- Kholifah Selorejo - Jombang.

\begin{tabular}{|l|c|c|}
\hline Kreativitas & Jumlah & Persentase \% \\
\hline Rendah & 9 & $53 \%$ \\
\hline Sedang & 6 & $35 \%$ \\
\hline Tinggi & 2 & $12 \%$ \\
\hline Total & 17 & $100 \%$ \\
\hline
\end{tabular}

Tabel 5 Distribusi Responden (kelompok perlakuan) Berdasarkan Kreativitas Anak Pra Sekolah Sesudah Bermain Puzzle di TK Al- Kholifah Selorejo - Jombang.

\begin{tabular}{|l|c|c|}
\hline Kreativitas & Jumlah & Persentase $\%$ \\
\hline Rendah & 2 & $12 \%$ \\
\hline Sedang & 6 & $35 \%$ \\
\hline Tinggi & 9 & $53 \%$ \\
\hline Total & 17 & $100 \%$ \\
\hline
\end{tabular}

Tabel 6 Distribusi Responden (kelompok kontrol) Berdasarkan Kreativitas Anak Pra Sekolah Sesudah Bermain Puzzle

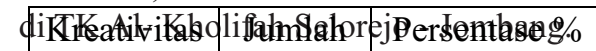

\begin{tabular}{|c|c|c|}
\hline Rendah & 9 & $53 \%$ \\
\hline Sedang & 6 & $35 \%$ \\
\hline Tinggi & 2 & $12 \%$ \\
\hline Total & 17 & $100 \%$ \\
\hline
\end{tabular}

Tabel 7 Pengaruh Bermain Puzzle terhadap Kreativitas pada Anak Prasekolah antara Kelompok Perlakuan dan Kelompok Kontrol di TK Al- Kholifah Selorejo - Jombang.

\begin{tabular}{|l|l|l|l|l|l|l|l|l|}
\hline \multirow{2}{*}{ Kreativitas } & \multicolumn{3}{|l|}{ Kelompok kontrol } & \multicolumn{3}{l|}{ Kelompok perlakuan } \\
\cline { 2 - 10 } & Pre-test & \multicolumn{2}{l|}{ Pos-test } & \multicolumn{2}{l|}{ Pre-test } & \multicolumn{2}{l|}{ Pos-test } \\
\cline { 2 - 9 } & $\sum$ & $\%$ & $\sum$ & $\%$ & $\sum$ & $\%$ & $\sum$ & $\%$ \\
\hline Tinggi & 2 & 12 & 2 & 12 & 2 & 12 & 9 & 53 \\
\hline Sedang & 6 & 35 & 6 & 35 & 6 & 35 & 6 & 35 \\
\hline Rendah & 9 & 53 & 9 & 53 & 9 & 53 & 2 & 12 \\
\hline Jumlah & 17 & 100 & 17 & 100 & 17 & 100 & 17 & 100 \\
\hline \multicolumn{3}{|c|}{$\rho: 0,00$} \\
\hline
\end{tabular}

4) Karakteristik Responden Berdasarkan Kreativitas Anak Pra Sekolah Yang Tidak Diberikan Bermain Puzzle (kelompok kontrol).

Tabel 6 menggambarkan bahwa lebih dari $50 \%$ responden (kelompok kontrol) mempunyai kreativitas rendah yaitu sebanyak 9 responden (53\%).
5) Pengaruh Bermain Puzzle terhadap Kreativitas Anak Prasekolah pada kelompok perlakuan dan kelompok kontrol (Pre dan post)

Berdasarkan Tabel 7 dapat dilihat bahwa kreativitas pada anak prasekolah pada kelompok perlakuan di antaranya, responden yang mempunyai kreativitas tinggi 53\%, 
kreativitas sedang 35\%, kreativitas rendah $12 \%$ dan pada kelompok perlakuan lebih besar dari pada kelompok kontrol, sedangkan pada kelompok kontrol kreativitas tinggi $12 \%$, kreativitas sedang 35\% dan kreativitas rendah $53 \%$.

Data hasil uji statistik yang peneliti lakukan untuk mengetahui pengaruh bermain puzzle terhadap kreativitas pada anak usia prasekolah (4-5 tahun) yang dianalisa menggunakan bantuan perangkat lunak SPSS 16 dengan uji paired sample T-test diperoleh nilai $=0,000<\alpha$ $(0,05)$. Dengan demikian H1 diterima atau H0 ditolak yang artinya ada pengaruh bermain puzzle terhadap kreativitas pada anak usia prasekolah (4-5 tahun) di TK Al- Kholifah Selorejo - Jombang.

\section{PEMBAHASAN}

\section{Pengaruh Bermain Puzzle terhadap} Kreativitas Anak Usia Prasekolah (4-5 tahun) pada Kelompok Perlakuan.

Ada beberapa macam permainan, baik ditinjau dari isi perminan maupun karakter sosialnya (Supartini,2004). Berdasarkan isi permainan :

Di antaranya bermain puzzle bermanfaat terhadap kreativitas yaitu memberikan saluran ekspresif untuk ide dan minat kreatif, memungkinkan fantasi dan imajinasi dan meningkatkan perkembangan bakat dan minat khusus.

Pada Tabel 5 menggambarkan bahwa sebagian besar responden (kelompok perlakuan) merupakan kreativitas yang tinggi yang sebagian besar 9 responden (53\%).

Puzzle gambar adalah permainan khas pada anak-anak, permainan tersebut dapat merangsang kecerdasan anak-anak dalam berfikir secara integral atau holistik dan melatih ketajaman otak anak dalam menyusun atau merancang sesuatu dengan baik (Malahayati). Dan menurut Yusuf (2010) beberapa faktor pendorong yang dapat meningkatkan kreativi- tas yaitu: Banyak membaca, Pengamatan secara seksama, Tingkat keberagaman pemikiran, Tingkat penghargaan terhadap waktu, Tingkat kekayaan fantasi, Tingkat berlatih cara-cara diskusi yang metodologis, dan Bonus-bonus baik berupa maknawi atau materi yang memiliki pengaruh besar dalam merangsang kreativitas.

Dengan demikian diharapkan pada setiap orang tua harus mengetahui ada beberapa hal yang perlu diperhatikan agar aktifitas bermain bisa menjadi stimulus yang efektif yaitu seperti, energi ekstra, waktu yang cukup, alat permainan, ruangan untuk bermain pengetahuan cara bermain, dan bermain.

\section{Pengaruh Bermain Puzzle terhadap Kreativitas Anak Prasekolah pada Kelom- pok Kontrol.}

Tabel 4 dan Tabel 6 menggambarkan bahwa sebagian besar responden (kelompok kontrol) mempunyai kreativitas yang rendah adalah 9 responden $(53 \%)$.

Permainan menyusun kepingan gambar sehingga menjadi gambar yang utuh disebut puzzle. Permainan ini tentu permainan yang sudah dikenal semua orang, bahkan mungkin di seluruh dunia. Semua golongan usia sangat menyukai permainan puzzle. Berbagai bentuk dan versi dihadirkan dalam variasi permainan puzzle. Kita dapat menemukan puzzle dalam jumlah kepingan yang cukup banyak dan fantastis karena gambar yang ditampilkan bias sampai ribuan jumlahnya. Tentunya bukan perkara mudah untuk menyusun puzzle yang ini. Kreativitas anak menjadi besar yaitu dengan cara stimulasi dari dini sedangkan responden kreativitas tetap karena tidak ada stimulasi (Supartini, 2004).

Dengan demikian diharapkan pada setiap orang tua untuk lebih sering memahami akan pentingnya kebutuhan bermain dan jenis permainan yang cocok pada anak dan mengetahui tahap-tahap perkembangan per usia anak. 
Sehingga dapat kita simpulkan bahwa ada perbedaan antara anak yang bermain puzzle dan tidak bermain puzzle terhadap ke kreativitasnya.

\section{Pengaruh Bermain Puzzle terhadap Kreativitas Anak Usia Prasekolah (4-5 tahun)}

Berdasarkan Tabel 7 dapat dilihat bahwa kreativitas pada anak pra sekolah pada kelompok perlakuan mempunyai kreativitas rendah adalah 2 responsen (12\%), kreativitas sedang adalah 6 responden $(35 \%)$, kreativitas tinggi adalah 9 responden (53\%) dan pada anak pra sekolah pada kelompok kontrol mempunyai kreativitas rendah adalah 9 responden (53\%), kreativitas sedang adalah 6 responden (35\%), kreativitas tinggi adalah 2 responden (12\%).

Berdasarkan uji paired sample T-test diperoleh nilai $=0,00<0,05$ dengan standarisasi $=0,05$. Dengan demikian H1 diterima atau H0 ditolak yang artinya ada pengaruh bermain puzzle terhadap kreativitas anak pra sekolah di TKAl-Kholifah Selorejo - Jombang.

Bermain mempunyai arti sangat penting bagi anak, yaitu untuk memenuhi kepuasan fisik, emosi dan perkembangan mental sehingga anak dapat mengekspresikan perasaan tentang kekuatan, kesepian, fantasi ataupun menunjukkan kreatifitasnya. Kebutuhan dan keperluan anak akan dapat terpenuhi secara optimal dengan kondisi keterbatasan yang dialaminya hal ini sangat penting diketahui oleh petugas atau perawat

Demikian dapat disimpulkan bahwa keterkaitan bermain puzzle dengan kreativitas yaitu, meningkatkan keterampilan kognitif, meningkatkan keterampilan motorik halus, dan menigkatkan keterampilan social. Kreativitas juga memberikan saluran ekspre-sif untuk ide dan minat yang kreatif, memungkinkan fantasi dan imajinasi, dan meningkatkan perkembangan bakat dan minat khusus. Orang tua juga harus memberikan kesempatan kepada anak untuk bermain agar anak dapat meningkatkan dan mengembangkan daya interaksi, imajinasi dan kreatifitas yang mereka miliki, serta jangan memaksakan sesuatu di luar kemampuan anak karena hal ini dapat berpengaruh pada perkembangan anak sendiri nantinya.

\section{KESIMPULAN}

Dari hasil penelitian dan pembahasan ini dapat ditarik simpulan yaitu:

1. Kreativitas yang dimiliki anak prasekolah pada responden pada pre-test kelompok perlakuan yaitu 9 responden (53\%) kreativitas rendah dan kelompok kontrol adalah 9 responden (53\%) kreativitas rendah.

2. Kreativitas yang dimiliki anak prasekolah setelah diberi perlakuan perlakuan bermain puzzle, pada kelompok perlakuan adalah 9 responden $(53 \%)$ untuk kreativitas tinggi, dan pada kelompok kontrol 9 responden (53\%) untuk kreativitas rendah.

3. Hasil analisa menunjukkan ada pengaruh bermain puzzle terhadap kreativitas anak prasekolah. Berdasarkan uji paired sample Ttest diperoleh nilai $=0,00<\alpha(0,05)$.

\section{DAFTAR PUSTAKA}

Arikunto, S. 1998. Prosedur Penelitian. Jakarta. Rineka Cipta. B. Sekartaji S. 2009. 101 Permainan Edukatif Untuk Anak. Yogyakarta: Pustaka Widyatama.

Basuki, H. Pengembangan Kreativitas. . (31 Juli 2007).

Hidayat, A. Aziz Alimul. 2003. Riset Keperawatan dan Teknik Penulisan Ilmuah. Jakarta. Salemba Medika.

Hurlock, E.B. 1991. Perkembangan Anak. Jakarta: Erlangga.

Markum, A.H. 1991. Ilmu Kesehatan Anak. Jakarta: FKUI.

Mulyadi, S. 2004. Bermain \& Kreativitas Upaya Mengembangkan Kreativitas Anak Melalui Kegiatan Bermain. Jakarta: Papas Sinar Sinanti.

Munandar, S.C.U. 1999. Mengembangkan Bakat dan Kreativitas Anak Sekolah Petunjuk bagi Orangtua dan Guru. Jakarta: PT. Grasindo.

Nursalam, S.P. 2003. Konsep dan Penetapan Metodologi Penelitian Ilmu Keperawatan. Jakarta: Salemba Medika.

Nursalam, S.P. 2001. Pendekatan Praktis Motodologi Penelitian Riset Keperawatan. Jakarta: Sagung Seto.

Pamilu, A. 2007. Mengembangkan Kreativitas \& Kecerdasar Anak. Yogyakarta:: Citra Media.

Rani Yulianty I. 2010. Permainan Yang Meningkatkan Kecerdasan Dan Kreativitas Anak. Jakarta: Laskar Aksara.

Safaria, T. 2005. Creativity Quptient Panduan Mencetak Anak Super Kreatif. Jogjakarta: Platinum.

Wahyudin. 2007. A to Z Anak Kreatif. Jakarta: Gema Insani. 